\title{
Jihadbevegelsen i den arabiske verdenen før og etter 2011
}

\begin{abstract}
Mange trodde den arabiske våren skulle bety slutten for jihadistbevegelsen. Men etter 2011 har den vunnet terreng i et omfang som de færreste kunne forestilt seg.
\end{abstract}

DE ARABISKE FOLKEOPPRøRENE I 2010 OG 2011, som tvang flere av Midtøstens mest notoriske autokrater fra makten, ble av mange tolket som et skudd for baugen for al-Qaida og jihadistbevegelsen.1,2 Demonstrantene på Tahrirplassen i Kairo var ikke-voldelige demokratiaktivister som ropte sekulære slagord som «Folket ønsker å velte regimet!» og «Brød, frihet og sosial rettferdighet!». Etter et tiår med intenst mediefokus på krigen mot terror var det nå de sekulære demokratiforkjempernes sin tur.

De var hovedrolleinnhaverne $\mathrm{i}$ et historisk drama der jihadistene ikke var stort annet enn marginale tilskuere. Flere Midtøstenkjennere tolket dette som et kraftig tilbakeslag for alQaida og dets slagord om at væpnet kamp er det eneste effektive virkemidlet for politisk endring. Drapet på al-Q Qaidas ubestridte leder Osama bin Laden i mai 2011 fremsto for flere som spikeren i likkista for terrornettverket: «Skuta synker og kapteinen er død» var en av kommentarene man kunne høre i ekspertmiljøet av jihadismekjennere.
Av Brynjar Lia, førsteamanuensis ved Institutt for kulturstudier og orientalske språk (Ikos), Universitetet i Oslo.

I september 2014, snart fire år etter starten på de arabiske folkeopprørene, er optimistismen fra 2011 fjernere enn noen gang. Ikke bare har jihadistbevegelsen overlevd den arabiske våren, men den har ekspandert og vunnet terreng $i$ et omfang som de færreste kunne ha forestilt seg. Per medio 2014 har jihadistbevegelsen flere mann under våpen, større territoriell kontroll og bredere geografisk nedslagsfelt i Midtøsten enn noen gang tidligere. . ${ }^{2}$ Langt fra å gjøre al-Qaida irrelevant ble folkerevolusjonene «en gave» til jihadistbevegelsen, hevder professor Marc Lynch ved Georgetown University. ${ }^{5}$ Hva har skjedd og hvordan kan man forklare dette dramatiske skiftet?

Denne artikkelen argumenterer for at jihadistbevegelsens ekspansjon må forstås som et utilsiktet resultat av folkeopprørene og et endret lokalt og internasjonalt fokus som til sammen har skapt helt nye rammebetingelser

IS-kriger i det nordlige Irak. Den islamske staten kontrollerer et område på størrelse med Storbritannia. 


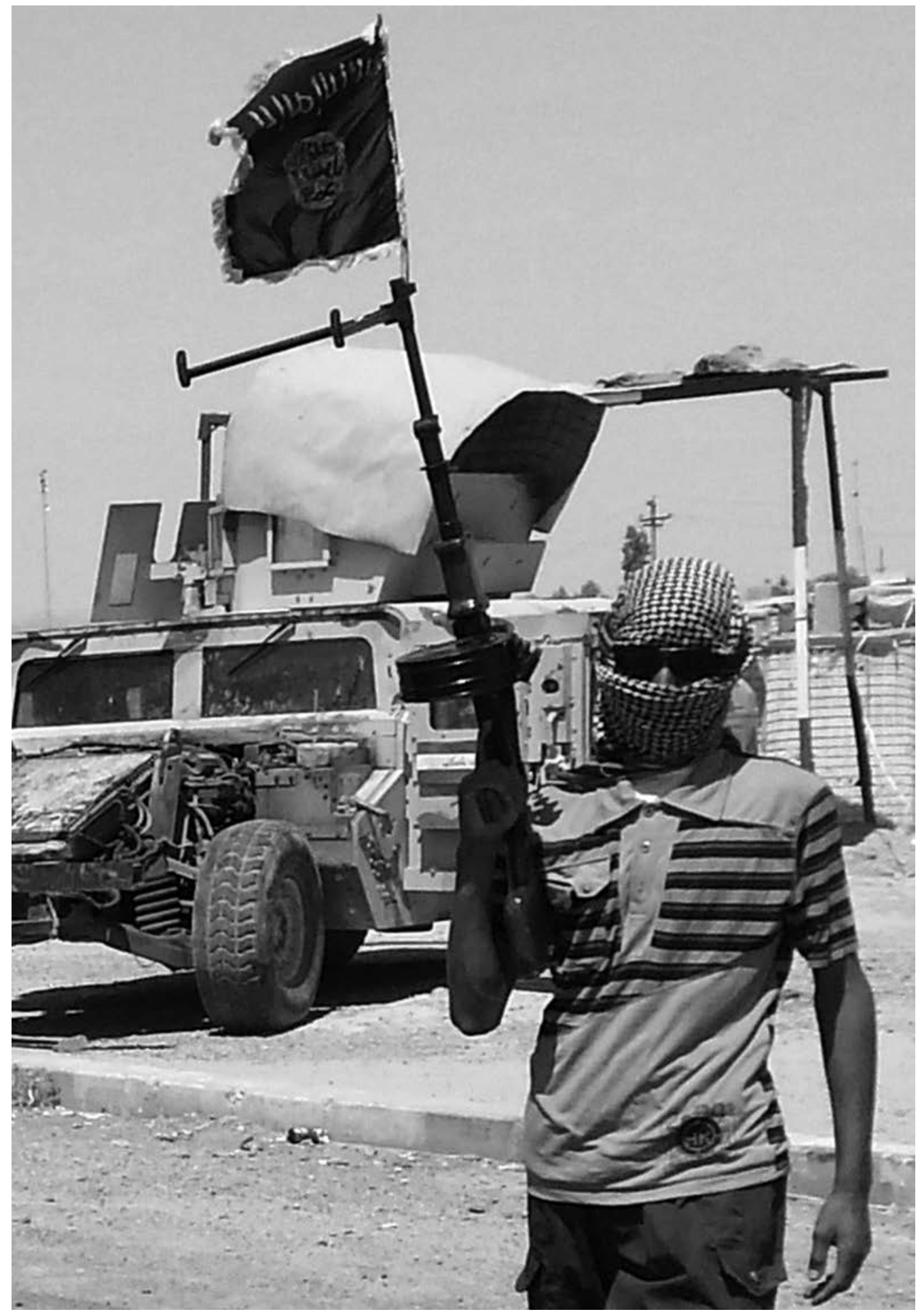


for radikale islamistgrupper i regionen. Statssammenbruddet i Libya, borgerkrigen i Syria, sterk intern uro, dyp politisk splittelse og maktkamp i Jemen og Irak og islamistiske valgseirer i Egypt og Tunisia har på ulike måter gitt større handlingsrom for jihadistgrupper i regionen. Den nye geopolitiske situasjonen i Midtøsten har også endret seg i jihadistenes favør: I desember 2011 fullførte usA sin militære tilbaketrekning fra Irak, samtidig som den syriske borgerkrigen skapte et kortvarig interessefellesskap mellom Vesten og militante islamister i Syria. Resultatet ble at jihadistgrupper i Syria har kunnet etablere store og relativt trygge baseområder i det nordlige Syria uten fare for amerikanske droneangrep og militæraksjoner.

Samtidig er det fremvoksende landskapet av nye jihadistgrupper i regionen preget av større spennvidde, sprikende agendaer og sterkere interne uenigheter enn noen gang tidligere. Sånn sett må tesen om «al-Qaidas comeback» i Midtøsten kvalifiseres. Det er langt på vei nye og mer lokalt orienterte jihadistgrupper som nå gjør seg gjeldende, og flere av disse er vesensforskjellige fra bin Laden og alZawahiris al-Qaida, både ideologisk og operasjonelt. Deres vekst skyldes i betydelig grad deres vilje til å utvide sin aktivitetsarena utover væpnet kamp til politisk orientert gateaktivisme, sosial velferd, bistandsarbeid. I tillegg har de demonstrert evne til å etablere effektive statsstrukturer i områder under deres kontroll, og de makter å utnytte effektivt sosiale medier som kommunikasjons- og propagandakanal.

\section{Al-Qaida og jihadistbevegelsen før 2011}

Al-Qaida forstås her som en organisasjon etablert av Osama bin Laden i 1988 med hovedkvarter og treningsleirer i AfPak-regionen (Afghanistan og Pakistan) siden slutten av 1990-tallet og med regionale, og relativt autonome, avdelinger i blant annet Irak, SaudiArabia, Jemen, Nord-Afrika og Somalia. Jihadistbevegelsen omfatter al-Qaida, men inkluderer også til en bredere bevegelse av opprørsgrupper, nettverk og sympatisører som i stor grad deler al-Qaidas ideologi, men står ikke i noe kommando- eller lojalitetsforhold til al-Qaidaledelsen. De jihadistgruppene hvis kommunikeer blir videreformidlet på de mest sentrale jihadistiske nettforaene, for eksempel shamikh1.info/vb/ er en god indikator på hvem jihadistbevegelsen består av.

Al-Qaidas historie siden 1988 til i dag kan gjerne inndeles i fem faser: (i) Etableringsfasen 1988-1996; (ii) Afghanistanfasen 1996-2001; (iii) På flukt etter Talibans fall (2001-2003); (iv) Irakkrigen og framveksten av lokale al-Qaidaavdelinger 2004 til 2011; (v) Al-Qaida etter den arabiske våren (2011- ).

Helt siden dannelsen i 1988 har organisasjonen vært i utvikling, og denne tilpasningsevnen har antakelig vært dets største styrke. I den tidlige fasen da al-Qaida var basert i Peshawar, var organisasjonen nærmest synonymt med kretsen rundt Osama bin Laden. Den gangen var ikke hovedfienden USA, men kommunistregimene i Kabul og sør-Jemen. I etterkant av Gulfkrigen i 1991 som førte til en vedvarende stasjonering av amerikanske styrker på Den arabiske halvøy, ble imidlertid al-Qaidas fokus i økende grad rettet mot usA. ${ }^{6}$ Fra sin nye base i Sudan mellom 1992 og 1996 etablerte al-Qaida seg som senteret i et globalt nettverk av lokale jihadistgrupper der kjernepersonene var «afghan-araberne» fra det internasjonale islamistmiljøet i Peshawar under Afghanistankrigen. Sånn sett var denne perioden startpunktet for det vi i dag kaller "jihadistbevegelsen».7 Store lokale jihadistgrupper som den egyptiske al-Gama'a al-Islamiyya og den algirske Groupe Islamique 
Armee hadde et mer distansert og anstrengt forhold til al-Qaida og motsatte seg ethvert forsøk på diktat utenifra. Mindre jihadistgrupper med færre egne ressurser var derimot langt mer mottagelige for et samarbeid med alQaida. Dette galdt blant annet den egyptiske jihadistgruppen Jama'at al-Jihad bi-Misr (Egyptisk Islamsk Jihad, EIJ) som under Ayman al-Zawahiris ledelse etablerte et tett samarbeid med bin Laden tilbake på 1980-tallet og fusjonerte EIJ med al-Qaida i 2001.

Perioden fra 1996 til 2001 var på mange måter al-Qaidas glansperiode. ${ }^{8}$ Sammenlignet med situasjonen i Sudan fikk al-Qaida langt større handlefrihet i Afghanistan, og organisasjonens virksomhet ble kraftig utvidet. De tre metaforene "storbedrift», "utdanningsinstitu-

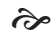 \\ Jihadistbevegelsens aktivitetsnivå har økt $i$} land som Libya, Tunisia og Egypt, de landene som var mest berørte av folkeopprørene.

sjon» og "fortropp» gir en idé om al-Qaidas rolle i denne perioden. Ved å yte finansiell, militær og annen støtte var al-Q_aida fødselshjelper for lokale islamistgrupper i Sørøst Asia, Nord-Afrika og Midtøsten. Ved å bistå i etableringen av treningsleirer i Afghanistan, Filippinene og Jemen, ble al-Qaida gradvis den mest sentrale utdanningsinstitusjonen for militante islamister. Betydningen av disse treningsleirene kan knapt nok overvurderes. ${ }^{9} \mathrm{Al}$-Q2aidas rolle som "fortropp» er tydeligst i terroraksjonene. Organisasjonen gjennomførte overraskende få aksjoner i denne perioden, men de var desto mer ambisiøse og spektakulære og var hver på sin måte nyvinninger innenfor terrorismens aksjonsformer. ${ }^{10}$

Perioden etter Talibans fall senhøstes 2001 til 2003 innledet en ny periode for al-Qaida preget av sterk svekkelse av organisasjonen og dets ressursgrunnlag i form av tilfluktsteder, treningsleirer, lederskikkelser og finansieringsmuligheter. Mange sentrale personer i al-Qaidas organisasjon ble enten drept eller tatt til fange, og dets operasjonelle miljø i de fleste verdensdeler ble langt mindre gjestmildt enn før på grunn av den usA-ledete krigen mot terror. Al-Qaidas appell økte derimot. Den enorme medieoppmerksomheten og det faktum at usA erklærte krig mot al-Qaida og på den måten fremhevet gruppen som en verdig motstander i en global duell, gjorde at al-Qaida oppnådde status som en antiimperialistisk kraft som våget å utfordre usAs verdenshegemoni. ${ }^{11}$ En viktig faktor $i$ denne sammenhengen var al-Qaidas fremvoksende medie- og propagandabyråer som nå gjorde organisasjonen bedre i stand til å promotere sin fortelling (narrative) og sin ideologiske forståelse av usAs krig mot terror. Al-Q_aidas liste over prioriterte angrepsmål ble også utvidet til å inkludere usas allierte i Midtøsten, hovedsakelig som respons på at disse landene, spesielt Jordan, Saudi Arabia og Egypt, stilte seg sammen med usA i kampen mot al-Qaida. Perioden 2003-11 ble sterkt preget av ettervirkningene av den usA-ledete invasjonen av Irak. Den påfølgende okkupasjonen skapte ikke bare grobunn for en økende mistro mot Vesten i den muslimske verden, men bidro også til etableringen av en meget slagkraftig irakisk opprørsbevegelse som al-Qaida kunne støtte seg på. Mellom 2004 og 2006 var Irak den desidert mest omtalte fronten i al-Qaidas propaganda og på al-Qaida-sympatiserende nettsider. ${ }^{12}$ Høsten 2004 etablerte dessuten al-Qaida sin første formelle regionale bransjeavdeling eller filial i nettopp Irak. Denne utviklingen mot regionalisering og dannelse av lokale al-Qaidaavdelinger og affilierte jihadistgrupper fort- 
satte i tiåret som fulgte med nye avdelinger i det sørlige Jemen, Maghreb, Somalia, og ikke minst i Syria. Al-Oaidas Irakavdeling, «alQaida i landet til de to elvene» (AQI), lyktes i å tiltrekke seg et stort antall rekrutter, hovedsakelig fra den arabiske verden, til selvmordsoppdrag i Irak. ${ }^{13}$ Utenfor Irak ble al-Qaidas terroraksjoner i stor grad motivert ut i fra situasjonen i Irak. ${ }^{14}$ I kjølvannet av Irakkrigen innledet al-Qaida også en lengre terrorkampanje i Saudi-Arabia under ledelse av en annen slagkraftig regional filial, al-Qaida på Den arabiske halvøy (AQAP) som vokste ut at et nettverk av tilbakevendte saudiske Afghanistanveteraner. ${ }^{15}$

Etter 2007 kom al-Qaida på defensiven i Irak. Dets forsøk på statsdannelse gjennom å utrope seg selv til Den islamske staten i Irak (ISI) strandet i mangel av reell territoriell kontroll og motbør fra andre irakiske sunniarabiske opprørere som mislikte isis brutale metoder og forsøk på å overta lokale lukrative smuglernettverk. I siste halvdel av 200o-tallet ble AQI/IsI desimert som resultat av rivalisering i den irakiske opprørsbevegelsen og en kraftig opptrapping av amerikansk troppenærvær i landet. Svakhet på et frontavsnitt kunne imidlertid oppveies med fremgang på andre «jihadfronter», herunder Afghanistan, Somalia og Jemen. Gjenetableringen av Afghanistanfronten er et godt eksempel på al-Qaidas evne til å skifte fokus og etablere relasjoner til lokale opprørsgeriljaer. Etter flukten fra Afghanistan i 2001-2 hadde al-Qaida viet forholdsvis lite oppmerksomhet til operasjoner i AfPakregionen, sammenlignet med Irak og SaudiArabia. ${ }^{16}$ Omslaget kom allerede i 2005 da fire sentrale al-Q Qaida-aktivister maktet å rømme fra fangeleiren ved den amerikanske basen i Bagram. Samtidig begynte Talibangeriljaen for alvor å gjøre seg gjeldende som en militær utfordring for koalisjonsstyrkene. I mai 2007 ble lederen for al-Qaida i Khurasans Land (AQA) utnevnt. I motsetning til dets søsteravdeling i Irak som tok mål av seg å lede hele opprørsbevegelsen, inntok AQA en langt mer ydmyk holdning til sin vertsorganisasjon, Taliban. AlQaida støttet Taliban med militære eksperter og rådgivere, spesielt innenfor propaganda- og medievirksomhet, og sloss i mindre geriljagrupper under overordnet ledelse fra Taliban og Haqqaninettverket. ${ }^{17}$

Intensiveringen av den amerikanske dronekrigen i Pakistan svekket imidlertid al-Qaidas operasjonsbase i AfPak-området. Derfor ble alQaidas avdeling i Jemen desto viktigere. Her også gjenoppstod organisasjonen på nytt som følge av en masseflukt av al-Qaidaveteraner fra

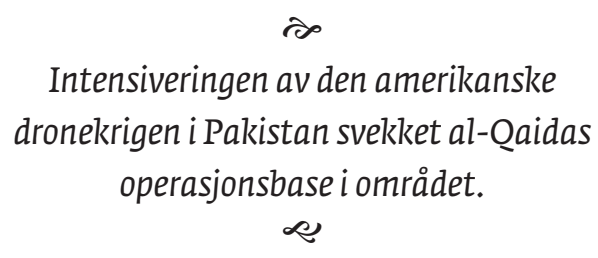

et fengsel i Sanaa i 2006, og fire år senere fremstod avdelingen som al-Qaidas desidert farligste på grunn av deres slagkraftige internasjonale enhet og en unik ekspertise i bombekonstruksjon. ${ }^{18}$ Fremgangen til den islamistiske Shabaab-geriljaen i Somalia der alQaida hadde vært aktiv på 1990-tallet, ble hilst velkommen i jihadistbevegelsen, og Shabaab responderte ved å adoptere jihadistisk retorikk og rekruttere flere fremmedkrigere. ${ }^{19}$ I februar 2013 sluttet geriljabevegelsen seg formelt til alQaida og avla lojalitetsed til Ayman alZawahiri. ${ }^{20}$

En svakhet ved al-Qaida i perioden før folkeopprørene i 2011 var dets relative mangel på slagkraftige avdelinger $i$ det sentrale Midtøsten, spesielt i landene som grenset opp mot Israel. Fremveksten av al-Qaida-lojale jihadist- 
grupper i Irak etter 2003 var således et kjærkomment tilskudd som representerte en strategisk viktig "framskutt base» nær de hellige stedene, i motsetning til de mer marginale baseområdene i perifere land som Afghanistan og Somalia. ${ }^{21}$ Nederlaget for al-Qaidas voldskampanje i Saudi-Arabia i 2003-2006 og desimeringen av Den islamske staten i Irak (ISI), al-Qaidas Irakavdeling, i 2007 var derfor betydelige tilbakeslag for bevegelsen og dets strategi om å vende tilbake til det sentrale Midtøsten. Et plaster på såret var at en viktig lokal opprørsgruppe, Groupe salafiste pour la prédication et le combat (GSPC) i Maghrebregionen, sluttet seg til al-Qaida som en fullverdig avdeling i 2007 under navnet al-Qaida i det islamske Maghreb (AQIM).

Ved inngangen til 2011 hadde ingen av landene i Midtøsten slagkraftige jihadistgrupper muligens med unntak av Algerie og Irak. I førstnevnte land som var herjet av borgerkrig på hele 1990-tallet, hadde antall terroraksjoner sunket betydelig igjennom hele 2000-tallet frem til 2011, avbrutt av et midlertidig oppsving i perioden 2004-6.22 AQIM var tydelig svekket i sitt tradisjonelle kjerneområde i nordøstlige Algerie, men hadde ekspandert noe sørover i Sahelregionen. Etter nederlaget i 2007 hadde AQI/ISI møysommelig maktet å gjenoppbygge organisasjonen, men AQI/ISIs aktivitetsnivå var fremdeles relativt lavt da borgerkrigen i Syria brøt ut. I 2012 økte antall AQI/ISI aksjoner med det tidoble. ${ }^{23} \mathrm{De}$ andre landene i Midtøsten hadde ingen jihadistbevegelser av strategisk betydning før 2011. Helt siden den store terroraksjonen i Luxor, Egypt i november 1997 som avrundet et langvarig islamistisk opprør mot Mubarakregimet, hadde den egyptiske jihadistbevegelsen ligget nede. Egypts ledende jihadistgruppe, al-Gama'a al-Islamiya, erklærte ensidig våpenhvile allerede i 1996, en våpenhvile de har holdt siden. Noen spredte aksjoner i sinai og Kairo på midten av 2000tallet illustrerte at mindre jihadistgrupper fremdeles fantes, men manglet evnen til langvarige kampanjer. ${ }^{24}$ Regimets intense antiterrorkampanje koblet sammen med et "deradikaliseringsprogram» for titusener av islamister i egyptiske fengsler tvang fram et ideologisk skifte. Flere av Egypts ledende jihadistideologer hevdet nå at voldsbruk for politisk endring ikke lenger var legitimt fordi det ikke ga resultater. ${ }^{25}$

Spredte forsøk på å etablere jihadistgrupper i Gaza førte heller ikke frem, selv om de representerte en ideologisk, og i mindre grad militær, utfordring for Hamas som styrte landstripen etter en maktovertagelse i 2007. ${ }^{26}$ På samme måte led jihadistene i Tripoli, Libanon nederlag da de utfordret den libanesiske hæren i mai 2007 gjennom et væpnet opprør i flyktningeleiren Nahr ElBared. ${ }^{27}$ Jordan hadde et aktivt islamistisk ekstremistmiljø med ledende ideologer som inspirerte og veiledet jihadister i en rekke land, men manglet selv lokale operative grupper. ${ }^{28}$ Syria hadde heller ingen væpnet intern opposisjon ved inngangen til 2011. Helt siden massakren som fulgte Hamaopprøret i 1982 var islamistbevegelsen omtrent fraværende som politisk kraft internt i Syria. Irakkrigen i 2003 skapte imidlertid et underlig interessefellesskap mellom militante salafister og det syriske Baathregimet da Bushadministrasjonen hintet om at Damaskus var nestemann på listen. Busstransport for "frivillige» til motstandskampen i Irak ble organisert fra Damaskus, ofte fra steder som var godt synlig fra den amerikanske ambassaden. Med en økende tilstrømning av militante salafister fra hele verden ble fremmedkrigerkontingenten såpass stor at den hjalp Ao I til å bli den dominerende aktøren i motstandsbevegelsen. Det gjorde 
pasifiseringen av Irak til en langt større utfordring enn Bush-administrasjonen hadde sett for seg. I ettertid skrøt syriske politikere åpenlyst til utenlandske besøkende om hvor vellykket deres strategi hadde vært. ${ }^{29}$ Dette kortvarige fornuftsekteskapet mellom Baathregime og militante islamister var langt fra stabilt, og mot slutten av 2000-tallet skjedde en rekke uforklarlige terroraksjoner i Syria som mer enn antydet at Assad-regimet også hadde en intern jihadistutfordring. ${ }^{30}$

\section{Jihadistbevegelsen etter 2011}

Det er liten tvil om at jihadistbevegelsen i den arabiske verden har vokst i omfang og slagkraft etter 2011. Ekspansjonen er imidlertid ikke jevn, men synes å være størst i de samme landene som opplevde den største uroen under folkerevolusjonene. Dersom vi bruker antall terroraksjoner per år som en indikator på jihadistbevegelsens styrke, avtegner det seg et mønster der folkerevolusjonseffekten er tydelig. ${ }^{31}$ Data fra Clobal Terrorism Database (GTD), den mest anerkjente databasen på terrorisme, viser at Egypt, Tunisia, Libya, Jemen og Syria har den mest dramatiske økningen $\mathrm{i}$ antall terroraksjoner. I flere av landene er det snakk om over en tidobling i antall aksjoner per år. Økningen er noe mindre i Jemen som allerede før 2011 hadde en slagkraftig jihadistgruppe (AQAP) og dessuten andre interne opprørsgrupper. Vi ser også i varierende grad en økning $i$ de arabiske republikkene Irak, Libanon og Algerie, spesielt i Irak fra 2011 og fremover. Disse landene ble som kjent mindre berørt av folkeopprørene, men hadde aktive jihadistgrupper i landet før 2011 og ble indirekte påvirket av statssammenbruddet i nabolandene Syria og Libya. De arabiske monarkiene som - med unntak av Bahrain - i stor grad unngikk voldelige masseopptøyer i 2011-12, har heller ingen merkbar øk- ning i antall terroraksjoner av jihadistgrupper etter 2011. Den regionen der jihadistgruppene har ekspandert aller mest etter 2011 er Syria og Irak, der opprørsgruppen Den islamske staten (Is) nå kontrollerer et større landområde og har flere titusen mann under våpen. Grunnlaget for denne ekspansjonen er sammensatt, men effektene av folkeopprørene i 2011 er, som vi skal se, en av de viktigste faktorene.

Mobiliseringsgrunnlaget til jihadistbevegelsen i Irak (AQI, ISI, ISIL, og IS) har helt siden midten på 200o-tallet vært Bagdadregjeringens manglende vilje til å inkludere den sunniarabiske minoriteten i Irak. Misnøyen $ø$ kte under Nouri al-Malikis shiadominerte regjering mellom 2006 og 2014, spesielt i siste del av perioden da Baghdad gikk tilbake på lovnader om å integrere den sunniarabiske minoriteten i de irakiske sikkerhetstyrkene og begynte avviklingen av Sahwa-militsene som hadde vært sentrale i å nedkjempe Aov/ISI i siste halvdel av 2000-tallet. ${ }^{32}$ Uttrekningen av amerikanske styrker fra Irak i slutten av 2011 bidrog til å minske det militære trykket mot opprørsgruppen. Dette sammenfaller med utbruddet av borgerkrigen Syria som skapte både handlingsrom og territoriell dybde for AQI/ISI. I grenseområdene til Syria fikk opprørsgruppen innpass $i$ et stort og uoversiktlig krigsteater med et stort antall tilreisende frivillige krigere, rike velgjørere, våpensmuglere og ideologiske våpenbrødre.

AQI/ISI var fra starten av en profesjonell og slagkraftig opprørsbevegelse som maktet å absorbere tidligere tilbakeslag, inkludert nederlaget i 2007.33 Selv om bortfallet av amerikanernes intense antiterrorkampanje var avgjørende for ISIs tilbakekomst, bidro flere andre omstendigheter i samme retning. Irakiske fengsler der titusener av sunniarabiske opprørere satt fanget, fungerte i mange tilfeller som sosialiseringsanstalter for Isı, der 
blant annet dets nåværende leder Abu Bakr alBaghdadi fikk noe av sin skolering. En serie av fengselsopprør og rømninger i juli 2013 brakte over fem hundre isi-medlemmer tilbake i organisasjonens rekker. ${ }^{34}$

Folkeopprøret mot det brutale Assadregimet i Syria åpnet for helt nye ekspansjonsmuligheter for Isı som nå for alvor ble en territoriell aktør. Etter å ha erobret territorier i Syria endret gruppen navn til Den islamske staten i Irak og Levanten (ISIL) i april 2013. Senere, etter den overraskende erobringen av Mosul og sentrale deler av vestlige Irak i juni 2014, kom nok en navnendring: Den islamske staten (Is) ble erklært opprettet. Organisasjonen plasserte seg selv ideologisk tett opptil irakisk sunniarabisk nasjonalisme og sjåvinisme. Med sitt intense hat mot Iran, Iraks shiamuslimske majoritet og kurdiske minoritet og sin brutale monopoliserende politikk overfor alle tenkelige rivaler har ISI/ISIL/Is mange likhetstrekk med det irakiske Baathpartiet. Og det er kanskje nettopp denne lokale tilpasningen som er noe av hemmeligheten til oppslutningen om organisasjonen i de sunniarabiske majoritetsområdene i Irak. Den islamske statens militære fremgang i 2013-14 skyldtes ikke bare det økte ressursgrunnlaget fra fristedene i Syria, men kan også forklares med is sin alliansepolitikk overfor andre sunniarabiske aktører, fra lokale stammeledere til gjenværende Baathpartistrukturer, representert ved blant annet Jaysh Rijal al-Tariqa al-Naqshbandiyya (JRTN). 35

Is sin brobyggingspolitikk er imidlertid kun kortsiktig og opportunistisk, og i takt med dets økende økonomiske og militære styrke fremstår organisasjonen som ekstremt territoriell i ordets videste forstand. Is vier mye mer ressurser til å konsolidere territoriell kontroll, sammenlignet med andre aktører $\mathrm{i}$ jihadist- bevegelsen. Utnevningen av is sin leder Abu Bakr al-Baghdadi til "Kalif Ibrahim» og etableringen av is som et kalifat (khilafa) i juni 2014 representerte det kanskje mest dramatiske skrittet i Is' maktdemonstrasjon vis-a-vis andre opprørsgrupper. Kalifat-erklæringen innebar en religiøs forpliktelse til lydighet og underkastelse og fremtvang således en enteneller situasjon der alle andre former for relasjon enn ren underkastelse var å betrakte som kjetterskap og forræderi.

Is sine maktambisjoner illustreres også ved at organisasjonen i lange perioder har prioritert utrenskning av jihadistiske rivaler og konkurrenter fremfor direkte konfrontasjoner med Assad-regimets militære styrker i Syria. ${ }^{36}$ De blodige konfrontasjonene mellom Isis/Is og Jabhat al-Nusra, al-Qaidas uoffisielle avdeling i Syria, har reist spørsmål om is representerer en fundamental trussel mot al-Qaidas lederposisjon i jihadistbevegelsen. ${ }^{37}$ En rekke

\section{Med sitt intense hat mot Iran, Iraks sjia- muslimske majoritet og kurdiske minoritet, har IS mye felles med Baathpartiet.}

av de nye jihadistgruppene som oppstod etter 2011, herunder Ansar Bayt al-Maqdis i Egypt, Ansar al-Shari'a Tunisia, og Jund al-Khilafa i Algerie, har uttrykt støtte til is og dets sitt nyopprettede kalifatet, på tross av at al-Qaidaledelsen har gått til det dramatiske skrittet å fraskrive seg enhver befatning med gruppen. ${ }^{38}$ Denne splittelsen bør imidlertid ikke tolkes som en svekkelse for jihadistbevegelsen som sådan. Is' forløpere, spesielt AQI/ISI, var også på kollisjonskurs med al-Qaidaledelsen.39 Væpnete sammenstøt mellom jihadistgrupper har vært begrenset til Syria, og den pågående usA-ledete bombeangrepene i Irak og Syria vil 
antakelig lede til økt samhold og slutting av rekkene. Det vi nå ser er antakelig fremveksten av en ny generasjon av jihadister som har fått større spillerom i regionen etter folkeopprørene og som nå ønsker en ny kurs og ser til IS for lederskap.

En viktig sideeffekt av folkeopprørene er at de $\mathrm{i}$ betydelig grad endret Midtøstens geopolitikk bort fra det ensidige fokuset på alQaida og krigen mot terror til et mer diffust konfliktbilde der autoritære arabiske regimer ikke lenger ble sett på som en uunnværlig alliert og stabiliserende faktor. Qaddafiregimets voldsbruk i 2011 banet vei for vestlig militær inngripen på opprørernes side, og det syriske Baathregimets brutalitet og kjemiske krigføring brakte usA og Vesten på kanten av en militær intervensjon til støtte for revolusjon. I Syria var usA og al-Qaida i realiteten på samme side i en konflikt. Dette gjorde at jihadistbevegelsen helt frem til oktober 2014 kunne ekspandere sitt nærvær i Syria uten frykt for dronekampanjer eller militære angrep fra en teknologisk sofistikert supermakt. Resultatet var etableringen av det største og mest langvarige friområdet (i nordlige Syria) som jihadistgrupper har hatt siden Talibanregimets fall i 2001. Det syriske regimet så seg også tjent med en "jihadisering og kriminalisering» av den syriske opprørsbevegelsen og rettet sine militære offensiver mot de moderate opprørsgruppene, mens isis fikk bygge sin ministat i nordlige Syria i fred. Hovedsetet for Isis/Is i Raqqa har inntil helt nylig unngått å tiltrekke seg Baathregimets flyvåpen og dets dødelige tønnebomber.40 Dette store friområdet, den relativt enkle tilgangen via grenseovergangene fra Libanon og Tyrkia og ikke minst jihadistbevegelsens uovertrufne transnasjonale mobiliseringsnettverk la grunnlaget for historiens største mobilisering av fremmedkrigere til et krigsteater. ${ }^{41}$ Anslagsvis 15 ooo fremmed- krigere sloss med jihadistbevegelsen i Syria og Irak, de aller fleste med Is, noe som langt på vei forklarer deres styrkeovertak vis-a-vis de moderate syriske opprørsgruppene. ${ }^{42}$

Selv om jihadistbevegelsens vekst etter 2011 er tydeligst i Syria og Irak, har også aktivitetsnivået i flere andre land i regionen økt betraktelig, fortrinnsvis i Libya, Tunisia og Egypt, de landene som var mest berørte folkeopprørene. I Egypt har det vokst fram en rekke nye jihadistgrupper der de Sinai-baserte gruppene Ansar Bayt al-Maqdis ( Misr er de mest kjente og slagkraftige. ${ }^{43} \mathrm{ABM}$ blir beskrevet som en blanding av eksil-palestinere fra Gaza som flyktet i 2010 da Hamas slo hardt ned på militante salafistnettverk; militante salafistpredikanter, misfornøyde beduiner, arbeidsledige marginaliserte unge menn og krigere med krigserfaring fra Irak og Syria, flere av dem med jordansk eller irakisk nasjonalitet. ${ }^{44}$ Med Is' økte status etter dets ekspansjon i Syria og Irak er det flere tegn på at egyptiske jihadistgrupper, spesielt ABM, søker mot is, blant annet for å få opplæring og tilegne seg ekspertise. ${ }^{45}$ Det illustrerer også hvordan jihadistbevegelsens ekspansjon i et teater påvirker situasjonen i andre land.

Det har vært en dramatisk økning i voldsnivået i Egypt, spesielt etter militærkuppet i juli 2013 mot den lovlig valgte regjeringen til Muhammad Mursi som i perioder hadde ført en forhandlingsorientert politikk overfor de Sinai-baserte militante gruppene. Mursis myke tilnærming sto i skarp kontrast til de militæres ønsker om kollektive avstraffelser og hevn for drap på egyptiske militære i Sinai, og var sannsynligvis en av årsakene til hans fall. ${ }^{46}$

Samtidig var kaoset etter Mubaraks avgang sterkt medvirkende til oppsvinget i militant virksomhet. Fengslede militante ble sluppet løs eller rømte fra ubevoktete fengsler, våpenlagre ble plyndret og smuglingen av 


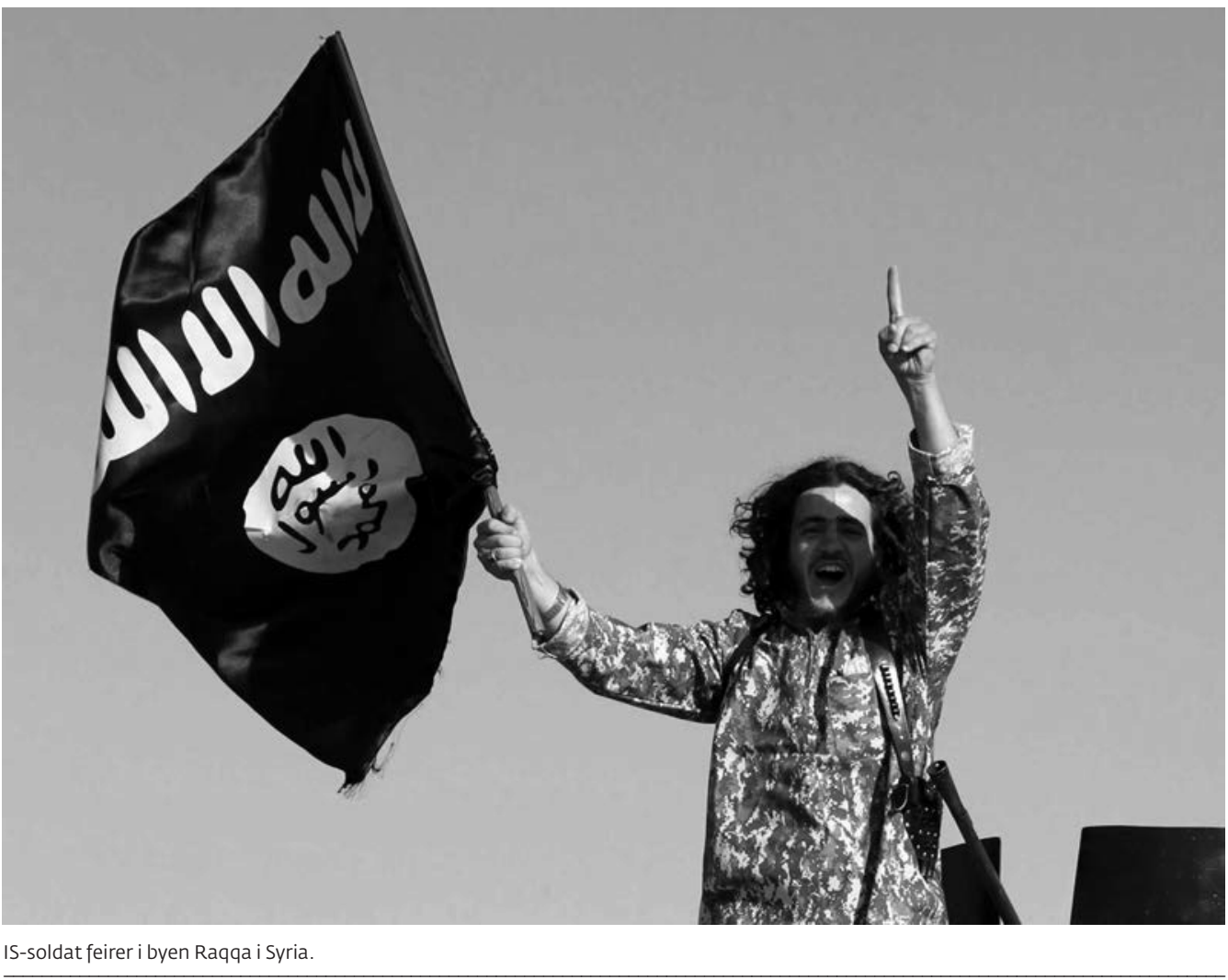

våpen fra blant annet Libya økte i omfang. I noen grad gjenoppstod jihadistmiljøer rundt eldre aktivister som tidligere var blitt "deradikalisert» under tvang i fengslene. Disse «old boys»-nettverkene var sentrale $\mathrm{i}$ å inspirere ungdommen til kamp ved jihadfronter i utlandet, men er i noen grad også blitt knyttet til nye terrorceller i Egypt. ${ }^{47}$

I tillegg fremsto Sinaihalvøya med sin lange og til dels dårlig bevoktete grense mot Israel og betydelige nærvær av vestlige observatørstyrker som et langt mer attraktivt frontområde for jihadistbevegelsen enn tidligere, nå som den egyptiske statsmakten var såpass svekket. I første omgang var det gassrørledningene til Israel som ble angrepet, men etter hvert ble også israelske grensemål, utenlandske freds- observatører, turister og ikke minst egyptiske sikkerhetstyrker rammet. På Sinaihalvøyen har situasjonen i perioder eskalert til regulær opprørskrig der den egyptiske hæren bruker tunge våpen, israelske droneangrep forekommer og grupper av beduinkrigere og radikale islamister gjennomfører militæraksjoner av et omfang som tidligere ville vært utenkelig. I sentrale byer i Egypt har dramatiske terroraksjoner funnet sted, herunder store koordinerte selvmordsaksjoner som i seg selv er et relativt nytt fenomen i Egypt. ${ }^{48}$

I Jemen er skiftet før og etter 2011 også merkbart, men ikke like dramatisk. Her fantes det allerede en relativt slagkraftig og dynamisk jihadistbevegelse. AQAP var den kanskje 
viktigste regionalavdelingen til al-Qaida i tiden før 2011. Med sin høye medieprofil og engelskspråklige jihadistpublikasjoner trakk AQAP til seg utenlandske jihadister fra mange deler av verden, inkludert Norge. Dets leder Nasir al-Wuhayshi er blitt utnevnt til «stabssjef" for hele al-Q Qaidanettverket, noe som signaliserer al-Qaidas ny prioritering av Midtøsten etter 2011. ${ }^{49}$ Alle tidligere stabssjefer i alQaida har vært baserte i AfPak-regionen.

Folkeopprøret mot president Ali Abdullah Salihs autoritære styre i 2011 skapte økt handlingsrom for AQAP. Uroen i Sanaa og splittelsen i det jemenittiske militære som til slutt veltet president Salihs regime, medførte blant annet at militærstyrker ble trukket ut av de sørlige provinsene. Lokale aktører fylte raskt dette maktvakuumet, og AQAP tilkjempet seg en rolle i dramaet, fortrinnsvis i de sørlige provinsene Abyan og Shabwa. I en lengre periode profilerte organisasjonen seg under navnet Ansar alShari'a og portretterte seg selv som en ministat som tilbød nødhjelp, velferd, sikkerhet og et rettferdig og rent islamsk styre til lokale innbyggere. En serie filmopptak og dokumentarer ble laget om de lokale islamiststatene «Emiratet av Zinjibar», "Emiratet av Jaar», etc, der "tilfeldige» innbyggere ble intervjuet om sin tilfredshet med det nye islamske styret. ${ }^{50}$ AQAP overdrev antakelig sin egen rolle og manglet dessuten ressursene til å styre og å holde territorier over tid. ${ }^{51}$ I 2012-13 ble AQAPS friområder gjenerobret, men AQAP er fremdeles en betydelig sikkerhetsutfordring i Jemen med høyt aktivitet og evne til å utnytte perioder med politisk uro i landet til egen konsolidering og ekspansjon. AQAPS promotering av seg selv som en statsaktør med vilje til å innføre islamsk styre og tilby innbyggerne sikkerhet og velferd representerte en stadig viktigere trend $\mathrm{i}$ jihadismen i den arabiske verden etter 2011.

Ansar al-Shari‘a-bevegelsen i Jemen var bare en av mange slike Ansar al-Shari'agrupperinger som oppstod i både Midtøsten og i Europa. Med sitt fokus på lokalt hjelpearbeid, velferd, gateaktivisme, islamsk moral, islamsk rettshåndheving et cetera, representerte disse bevegelsene en mykere utgave av al-Qaidas jihadisme der tilpasning til lokale forhold er viktigere enn den globale militære kampen. Jihadismekjenneren Aaron Zelin mener Ansar al-Shari'a-bevegelsene representerer en tilbakevending til en mer "multipolar jihadosfære», mer lik den situasjonen man hadde på 1990-tallet før al-Qaidas globale jihad og USAS krig mot terror ble det dominerende paradigmet. ${ }^{53}$ Denne parallellen er imidlertid bare delvis dekkende. Dagens Ansar al-Shari'abevegelser er mer integrert i globale mobiliseringsnettverk gjennom sosiale medier og omfattende reisevirksomhet, enn det 1990tallets jihadistgrupper var. De rekrutterer til, og deltar i, fremmedkrigeraktivitet i et omfang som deres forgjengere ikke gjorde. Tunisias Ansar al-Shari'a-bevegelse er et eksempel. Anslagsvis 3000 tunisiere har reist som fremmedkrigere til Syria siden 2011, og Ansar al-Shari‘a aktivister antas å være sentrale i denne mobiliseringen. ${ }^{54}$

Den lokalt fokuserte og statsbyggende ambisjonen til jihadisgruppene er ikke helt ny, men er blitt stadig viktigere etter 2011. De eneste reelle eksemplene på jihadistiske statsbyggingsprosjekter før 2011 i den arabiske verden var AoIs Den islamske staten i Irak (ISI) i 2006, et prosjekt som ble møtt med stor skepsis i jihadistbevegelsen.55 Etter 2011 ble det imidlertid etablert «emirater» av jihadistgrupper $\mathrm{i}$ Jemen, Syria og Mali, i tillegg til en gjenetablering av den islamske staten i Irak. ${ }^{56} \mathrm{En}$ parallell utvikling så man i det nordlige Mali der en islamistisk ministat oppstod i 2012-13, delvis i samarbeid med lokale tuaregopprørere, inntil en fransk militærintervensjon («Ope- 
ration Serval») satte en (midlertidig?) stopper for statsprosjektet. ${ }^{57}$

Ministaten i Mali og dannelsen av flere lokale avleggere av AQIM, al-Qaidas opprinnelige avdeling i regionen, hadde ikke vært mulig uten de endringene som de arabiske folkerevolusjonene skapte i Nord-Afrika. Mest vidtrekkende konsekvenser fikk opprøret mot Qaddafis regime i 2011 og det påfølgende statssammenbruddet i landet. Libya under Qaddafi er blitt beskrevet som verdens største "parkeringsplass» for konvensjonelle våpen, et resultat av diktatorens umettelige appetitt på våpen og nærmest utømmelige oljeinntekter. ${ }^{8}$ Oppløsningen av statens voldsmonopol etter Qaddafis fall førte til at betydelige deler av dette enorme våpenarsenalet kom på private hender og ble eksportert eller smuglet til andre konfliktsoner i regionen, herunder Mali, Sinai, Gaza, Libanon og Syria. Våpenstrømmen fra Libya har vært en sentral faktor bak opprøret i Sinai, og har vært en av de viktigste våpenforsyningslinjene til syriske opprørere. ${ }^{59}$

Den økte våpentilgangen har ikke bare militarisert lokale islamistgrupper som uten våpentilgang ville måtte forbli demonstranter eller undergrunnsaktivister. Den økte våpentilgjengeligheten har også styrket den internasjonale jihadistbevegelsen som med sine effektive transnasjonale nettverk evner å nyttiggjøre seg disse ressursene. Dette ser vi tydeligst i Syria der opprøret startet ved at ubevæpnete demonstranter protesterte i en lokalprovins mot tortur og overgrep. Da konflikten eskalerte og avhoppere fra den syriske hæren dannet Den frie syriske hær (FSA), ble de etter forholdsvis kort tid overskygget og marginalisert av langt bedre organiserte jihadistgrupper, fortrinnsvis Jabhat al-Nusra og Isıs. Interne splittelser i den sekulære syriske opposisjonen og utbredt vestlig skepsis til å forsyne opprørerne med våpen er bare en del av forklaringen. Med sine globale nettverk av ideologiske tilhengere (pengeinnsamlere, forkynnere, fasilitatorer og datakyndige aktivister) og lange erfaring i klandestin organisering har jihadistene vært langt mer effektive enn de syriske offiserene i FSA hvis militære bakgrunn fra den klaustrofobiske syriske hæren hadde gjort dem lite egnet til transnasjonal ideologisk mobilisering.

\section{Konkluderende merknader}

Dersom vi skal trekke frem noen mer overordnete forklaringer på overlevelsesevnen og fremgangen til jihadistbevegelsen i de omskiftelige omstendighetene som har preget Midtøsten siden 2011, er det særlig to forhold som kan være illustrerende, nemlig ideologisk smitteeffekt og den «ikke-territorielle» karakteren til pan-ideologiske opprørsbevegelser.

Med ideologisk smitteeffekt menes her den spredningseffekten som skapes gjennom langvarig massiv mediedekning av en opprørsgruppe som står for spektakulære og dramatiske terroraksjoner og som gjennom sine voldsaksjoner makter å utfordre og i noen grad ydmyke de etablerte maktsentraene. ${ }^{61}$ PLFPS dramatiske flykapringer i Amman i 1970 som ble kringkastet til hele verden, er ett godt eksempel. En lang rekke militante grupper etterapet PLFPS aksjoner utover 1970-årene. Hver tidsepoke tenderer til å ha én eller et fătall varianter av revolusjonære ideologier som motiverer til opprør og kamp. David Rapoport har kalt dette de fire moderne bølgene i moderne terrorisme, der hver generasjon tenderer til å ha én dominerende ideologisk orientering. Denne har skiftet fra anarkisme til antikolonialisme og senere fra marxisme til militant islamisme. ${ }^{62}$ Man kan derfor betrakte jihadisme som en hegemonisk rebellideologi som lettere adopteres av nye militante grupper enn mindre kjente ideologiske retninger. Jiha- 
dismen har vist seg potent og slagkraftig, og den tilbyr et globalt fellesskap med likesinnete opprørere. De nye Internett-baserte mediene skaper dessuten rom og arenaer for å bygge denne type globale ideologiske felleskap.

En annen forklaring på jihadistbevegelsens kontinuerlige appell er dets «ikke-territorielle» karakteren karakter. Med dét menes at jihadistene ideologisk sett ikke er bundet til ett spesifikt territorium slik nasjonalistiske frigjøringsbevegelser er, jamfør PLO, PKK og Polisaro. Jihadistbevegelsens fremtid avgjøres dermed ikke av tilbakeslag på ett frontavsnitt eller i ett land. Ved å omdefinere kampen fra nasjonale bestrebelser for en islamsk stat til en global kampanje for islamsk frigjøring og et fremtidig verdenskalifat makter jihadistene således å gjøre bevegelsen langt mer motstandsdyktig. ${ }^{63}$ Gjennom en slik desentralisert organisering kan enhver jihadist i prinsippet "velge sin jihad» og sin organisasjon, det være seg AQAP i Jemen, AQIM i Nord-Mali, Is i Syria og Irak eller «Emiratet» i Nord-Kaukasus.

Slik sett fremstår jihadistbevegelsen som et delvis de-territorialisert opprør der raske overflytninger til nye kamparenaer ikke bare er mulig, men også ønskelig. Den eksplosjonsartede veksten i al-Qaidas Irakavdeling etter 2003 er illustrerende på hvor raskt jihadistbevegelsen kunne bygge seg opp i et land uten en hjemlig jihadistbevegelse. Noe tilsvarende så vi i Syria etter 2011. Mobiliseringen av fremmedkrigere, betydelig tilgang på ekstern finansiering og et effektivt apparat av nettkyndige medieaktivister er noe av grunnlaget for jihadistgruppenes styrke og mobilitet. Dette de-territorialiserte aspektet ved jihadistbevegelsen forhindrer likevel ikke at mange av de nye militante islamistgruppene som har oppstått i Midtøsten etter 2011, fra Ansar Bayt al-Maqdis til Ansar al-Shari'a Tunisia, har sterke lokale forankringer og lokale agendaer.
Den territorielle faktoren er fremdeles viktig. Den pågående rivaliseringen mellom alQaida-lederskapet og Isis/Is har sin basis i at sistnevnte har ekspandert utover sitt tradisjonelle baseområde i Irak og etablert nettverk av likesinnede og sympatiserende grupper på samme måte som al-Q̃aida selv ekspanderte på 1990-tallet. Is' økende popularitet blant unge jihadistsympatisører, både i Midtøsten og Europa utgjør per dags dato kanskje den største ideologiske trusselen mot det gamle al-Qaidalederskapet.

Dette viser også hvor kritisk den globale og panislamistiske karakteren til jihadistbevegelsen er for dets langsiktige overlevelse. Midtøsten har lange tradisjoner for transnasjonale ideologiske bevegelser, fra al-Afghanis tidlige panislamisme til Baathpartiets panarabisme og islamistbevegelsens panislamske solidaritetsbevegelser. I denne rike tradisjonen har dagens jihadistbevegelse maktet å tilrive seg en plass.

\section{$\cdot f \cdot$}

1 Jeg vil takke Petter Nesser, Truls Hallberg Tønnessen, Anne Stenersen, Tine Gade og to anonyme fagfeller for nyttige kommentarer til artikkelen.

2 Det empiriske grunnlaget for denne artikkelen er en blanding av sekundærlitteratur, pressekilder, analyse av data fra Clobal Terrorism Database (CTD) og forfatterens egen lesning av jihadistbevegelsens medieproduksjon som forfatter har fulgt siden 1999. På grunn av tidsskriftets konsise format er det ikke mulig å gi fullstendig redegjørelse for kildene. Artikkelen mă derfor betraktes som et innspill til debatt om jihadistbevegelsens utvikling etter 2011.

3 Se for eksempel kommentaren til Ian Black, "Al-Qaida already looked irrelevant after Arab Spring", The Cuardian, 2. mai 2011.

4 Se $\mathrm{f}$ eks "IS has 20,000-31,500 fighters in Iraq and Syria: CIA", Associated Press, 12. september 2014.

5 Marc Lynch, "The Gift: How the Arab Spring turned out to be a win for al-Qaeda”, ForeignPolicy.com, 8 august 2013.

6 For to gode studier om al-Qaida i denne perioden, se Vahid Brown, Cracks in the Foundation: Leadership Schisms in Al-Oa'ida from 1989-2006. West Point, New York: CTC, 2007 og Al-Qaida's (Mis)Adventures in the Horn of Africa. West Point, New York: CTC, 2006.

7 Man finner begrepet «jihadist» i arabiskspråklig islamistlitteratur fra ca 1990 og fremover. Se f eks Omar 
Abd al-Hakim, al-Thawra al-Islamiyya al-Jihadiyya fi Suria. Peshawar, 1991.

8 For en oversikt over al-Oaidas kommunikeer i denne perioden, se Thomas Hegghammer, Dokumentasjon om alQaida: intervjuer, kommunikeer og andre primcerkilder, 1990-2002, Kjeller: FFI, 2003.

9 Thomas Hegghammer, "Al-Qaidas rekruttskoler: Hva gjorde Afghanistan-veteranene så farlige?”, Norsk Militært Tidsskrift, $2 / 2008$.

10 Brynjar Lia, "What is terrorism?", Winds of Change: On Irregular Warfare. Helsinki: National Defence University of Finland, Publication series, N:0 18, 2012, s. 360-374.

11 Se Brynjar Lia, "Al-Qaida's Appeal: Understanding its Unique Selling Points", Perspectives on Terrorism, 2 (8) (mai 2008), s. 23-28.

12 Se Thomas Hegghammer, "Irak-konflikten i radikal islamistisk ideologi”, Internasjonal Politikk, 63 (4) (2005), s. $351-370$.

13 Se f eks Thomas Hegghammer, Saudi militants in Iraq - backgrounds and recruitment patterns. Kjeller: FFI, 2006.

14 Petter Nesser, "Jihadism in Western Europe After the Invasion of Iraq: Tracing Motivational Influences from the Iraq War on Jihadist Terrorism in Western Europe", Studies in Conflict and Terrorism, 29 (4) (juni 2006), s. 323-342.

15 For bakgrunnen for denne kampanjen, se Thomas Hegghammer, Jihad in Saudi Arabia: Violence and Pan-Islamism since 1979. Cambridge: Cambridge University Press, 2010.

16 For al-Qaidas deltakelse i krigen i Afghanistan, se den prisbelønte artikkelen Anne Stenersen, "Al-Oaidas fotsoldater i Afghanistan”, Norsk Militært Tidsskrift, nr. 4/2009.

17 Se Anne Stenersen, "Blood Brothers or a Marriage of Convenience? The Ideological Relationship between alQaida and the Taliban". Paper. The Annual International Studies Association Convention (ISA), New York, 14-18. februar 2009.

18 En av de beste studiene av AOAP i Jemen er Gabriel KoehlerDerrick (red.) A False Foundation? AQAP, Tribes, and Ungoverned Spaces in Yemen. New York: CTC, 2011.

19 Stig Jarle Hansen, Al Shabaab in Somalia: The History and Ideology of a Militant Islamist Group, 2005-2012. London: Hurst, 2013.

20 "Somalia's al-Shabab join al-Qaeda", BBC.co.uk, 10. februar 2012

21 For al-Qaidas strategiske betraktninger om dette, se Brynjar Lia og Thomas Hegghammer, "Jihadi Strategic Studies: The Alleged Al Oaeda Policy Study Preceding the Madrid Bombings", Studies in Conflict and Terrorism, 27, 4 (sep/okt 2007), s. 355-375.

22 Data fra Global Terrorism Database.

23 Det er 32 AQI/ISI-aksjoner i Irak i 2011 og hele 301 i 2012, ifølge databasen Clobal Terrorism Database (CTD). Se også "ISIS: The unsurprising surprise that is sweeping Iraq", Bulletin of the Atomic Scientists, 18.juni 2014

24 Heidi Breen, Violent Islamism in Egypt from 1997 to 2012, Kjeller: FFI, 2013,

25 Omar Ashour, The De-Radicalization of Jihadists: Transforming Armed Islamist Movements. London: Routledge, 2009; og Paul Kamolnick, "Al Oaeda's Sharia Crisis: Sayyid Imam and the Jurisprudence of Lawful Military Jihad", Studies in Conflict
\& Terrorism, 36 (5) (2013), s.394-418.

26 International Crisis Group, Radical Islam in Caza. Brussel, 2011; og Are Hovdenak, Al-Qaida - a challenge for Hamas? Kjeller: FFI, 2009

27 Tine Gade, Fatah al-Islam in Lebanon: Between global and local jihad, Kjeller: FFI, 2007.

28 Joas Wagemakers. A Quietist Jihadi: The Ideology and Influence of Abu Muhammad al-Maqdisi. Cambridge University Press, 2012.

29 Seminar med syriske politikere i Damaskus, vår 2010.

30 "Syrian car bomb attack kills 17", BBC.co.uk, 27.september 2008; og "Five die as Syria thwarts attack", BBC.co.uk, 2. juni 2006 .

31 Nedenfor diskuteres tallene fra Global Terrorism Database (http://www.start.umd.edu/gtd/), som drives av University of Maryland i USA. Tallene som oppgis baserer seg på strengeste søkekriterier der bl a planlagte aksjoner ikke tas med. I analysen av tallmaterialet må det tas hensyn til at noen av disse landene har innenlandske terrorgrupper som ikke er jihadister og at mange av de registrerte terrorhendelser ikke har kjent gjerningsperson. Egypt: det er registrert 13 terrorhendelser i perioden 2000 10 og hele 216 hendelser i perioden 2011-13. Økningen etter 2011 er med andre ord dramatisk. "Ansar Jerusalem» (dvs Ansar Bayt al-Maqdis), "Egyptian Tawhid and Jihad», og uspesifiserte "Muslim fundamentalists" står bak de fleste av aksjonene der antatt gjerningsperson er oppgitt. Tunisia: Databasen har kun tre registrerte terrorhendelser i perioden 2000-10, mens det er hele 14 hendelser perioden 2011-13. Fire av disse tilskrives Ansar al-Shari'a Tunisia, ett antas å være utført av AOIM og fire tilskrives "Muslim fundamentalists". Jemen: Databasen inneholder 475 terrorhendelser for perioden 2011-13, mens det perioden 2000-2010 er registrert 172 aksjoner. I begge periodene er AQAP er det hyppigst forekommende navnet 1 de hendelsene det mistenkte eller kjente gjerningspersoner oppgis. Det er et merkbart skifte etter 2011, men økningen kommer fortrinnsvis i 2012 og 2013 da antall terrorhendelser ligger på et betraktelig høyere nivå enn før folkerevolusjonene. Cjenerobringen av AQAPs friområder er antakelig den viktigste årsaken til voldsøkningen. Libya: Kun 2 registrerte terrorhendelser i perioden 2000 2010, mens det er hele 242 terrorhendelser i perioden 20112013. De aller fleste har ukjente gjerningspersoner, men ca 20 hendelser tilskrives militante islamistgrupper. Irak: Det er registrert 4.663 terrorhendelser i perioden 2011-2013 sammenlignet med 5.576 hendelser i perioden 2000-2010. Her er det også en økning etter 2011, og kurven stiger særdeles kraftig i 2013. Libanon: Databasen har registrert 120 terrorhendelser i perioden 2000-2010. Blant de antatte bakmennene finner man jihadistiske aktører (Fatah alIslam, Jund al-Sham, Asbat al-Ansar, etc), men forholdsvis mange hendelser tilskrives ikke-jihadistiske grupper. For perioden 2011-2013 er det registrert hele 92 terrorhendelser der sunnimuslimske og jihadistiske grupper forekommer oftest blant antatte "perpetrators" (Abdallah Azzambrigadene, Jund al-Sham, sunnimuslimske anti-Hizbullah grupper). Algerie: Det er registrert 43 terrorhendelser for perioden 2011-13 der nesten halvparten av aksjonene antas å være utført av AQIM eller en av dets avleggere. Det er registrert 792 terrorhendelser i perioden 2000-2010, og det relativt høye tallet skyldes kampen mot gjenværende islamistiske geriljagrupper (fortrinnsvis CSPC, senere AOIM) fra den algeriske borgerkrigen på 1990-tallet. Trenden er nedadgående, med et midlertidig oppsving $\mathrm{i}$ perioden 2004-6, etterfulgt av en fortsatt nedgang frem til 2011. Her også ser vi en økning etter 2011. Det er for så vidt en kortvarig økning, men én av aksjonene etter 2011 skiller seg kraftig ut. Det er "In Amenas»-aksjonen i 2013 med 69 drepte, en særdeles omfattende og dramatisk kapringsaksjon som savner sidestykke i moderne terrorisme i Midt- 
østen når det gjelder oljerelaterte mål. Marokko: Én terrorhendelse i perioden 2011-2013. Det var en AOIMoperasjon med 17 drepte. For perioden 2000-2010 er det registrert 11 terrorhendelser der AQIM og Salafiyya Jihadiyya er oppførte som antatte gjerningsmenn, med totalt 53 drepte. Jordan: Her finner vi 10 hendelser for perioden 2000-2010 der halvparten tilskrives al-Oaida eller militante islamister, og bare to hendelser i perioden 201113. Saudi-Arabia: Det er registrert 36 hendelser i perioden 2000-2010 og 13 terrorhendelser i perioden 2011-2013. Bare ett av angrepene etter 2011 tilskrives AQAP.

32 "ISIS: The unsurprising surprise that is sweeping Iraq", Bulletin of the Atomic Scientists, 18.juni 2014.

33 Se diskusjonen om AOI/ISI i Michael Scheuer, Osama bin Laden. Oxford: Oxford University Press, 2012.

34 "Al Qaeda says it freed 500 inmates in Iraq jail-break", Reuters, 23.juli 2013.

35 Denne alliansen med tidligere Baathpartilojalister var imidlertid i ferd med å gå i oppløsning på høstparten i 2014. Se Shane Harris, "The Re-Baathification of Iraq", ForeignPolicy.com, 21. august 2014.

36 Sarah Birke, "How al-Qaeda Changed the Syrian War", The New York Review of Books, 27. desember 2013.

37 Se f eks diskusjonen i Charles Lister, "The 'Real' Jabhat alNusra Appears to Be Emerging", Huffington Post, 7.august 2014.

38 "Al-Qaeda disavows any ties with radical Islamist ISIS group in Syria, Iraq", Washington Post, 3.februar 2014; og "Egyptian Militant Group Pledges Loyalty to ISIS", New York Times, 10. november 2014.

39 Under al-Zarqawis lederskap frem til 2006 ble gruppen kritisert av al-Qaidaledelsen for egenrådighet og doktrinær fanatisme som satte organisasjonens langsiktige mål i fare. Overdreven brutalitet var imidlertid bare et underordnet aspekt ved Zarqawis konflikt med al-Qaidaledelsen. Se Brynjar Lia, "Jihadi Strategists and Doctrinarians", Assaf Moghadam og Brian Fishman (red.) Self-Inflicted Wounds Debates and Divisions within al-Qa'ida and its Periphery. West Point, NY: Combating Terrorism Center, 2010, s.100-131.

40 Jeg står i gjeld til professor François Burgat for denne observasjonen. Francois Burgat, "No Spring for Syria. What Went Wrong?", Forelesning, Senter for Islam og Midtøstenstudier (SIMS), Universitetet i Oslo, 4.april 2014.

41 Thomas Hegghammer, "Syria's Foreign Fighters", ForeignPolicy.com, 9.desember 2013.

42 "IS has 20,000-31,500 fighters in Iraq and Syria: CIA", Associated Press, 12.september 2014; Richard Barrett, "For eign Fighters in Syria", The Soufan Croup - Report, juni 2014; og "UN: Foreign Fighters Joining Terror Groups On 'Unprecedented Scale',' Huffington Post, 31.oktober 2014.

43 "Profile: Egypt's militant Ansar Beit al-Maqdis group", bbc.co.uk, 24.januar 2014; "New Egypt terror group adopting 'lone wolf' approach", Al-Monitor, 3.juli 2014; og "Jihadist Return Is Said to Drive Attacks in Egypt", New York Times, 5. februar 2014.

44 “ISIS Affiliate Turns on Egypt: 26 Killed, 26 Injured”, Newsweek, 25. oktober 2014.

45 "ISIS guides Egyptian militants, expanding its influence", Daily Star, 6. september 2014.

46 "Sinai's Role in Morsi's Ouster", Sada/carnegie endowment.org, 20. august 2013.
47 Se f eks "State Department designates longtime Zawahiri subordinate", Long War Journal, 7.oktober 2013; og Thomas Joscelyn, "Al-Qaeda's expansion in Egypt", Hearing before the House Committee on Homeland Security, 11. februar 2014.

48 "Egypt militants step up campaign with Cairo blasts", bbc.co.uk, 24.januar 2014; og "The Jihadist Threat in Egypt's Sinai”, Al-Monitor, 22.juli 2014.

49 "AQAP's emir also serves as al Qaeda's general manager", Long War Journal, 6 august 2013.

50 Se f eks Madad News Agency, "Sharia law in Yemen (Ansar Al-Sharia) - قعبرش راحنا" YouTube.com, 8.februar 2012.

51 Gabriel Koehler-Derrick (red.) A False Foundation? AQAP, Tribes, and Ungoverned Spaces in Yemen. New York: CTC, 2011, s.101.

52 "Al Oaeda resurgent in Yemen amid political turmoil", CNN.com, 18.oktober 2014

53 "Know Your Ansar al-Sharia", 21 September 2012, wash ingtoninstitute.org/policy-analysis/view/know-youransar-al-sharia

54 For en diskusjon om årsakene til de høye tallene i Tunisia, se "The curious case of the Tunisian 3,000", OpenDemoracy.net, 19. juli 2014.

55 Den somaliske Shabaabgeriljaen langt større suksess som statsaktør i sørlige Somalia på slutten av 200o-tallet.

56 En rekke mindre grupper fra Sinai til Libya erklærte dessuten etableringen av lokale "emirater". Se f eks "Ansar Sharia in Libya declare Benghazi 'Islamic emirate',", Arab Online, 31.juli 2014.

57 For indikasjoner på en revitalisering av jihadistgruppene i regionen, se "Jihadists return to northern Mali a year after French intervention", Guardian, 14.mars 2014.

58 Anthony Cordesman, A Tragedy of Arms. Military and Security Development in the Maghreb. Westport: Praeger, 2002, s. 220.

59 Se f eks "Smuggled Libyan weapons flood into Egypt", Washington Post, 12.oktober 2011; "What Is Libya's Connection To The Sinai Clashes? Post-Revolution Security Vacuum A Threat To Egypt, Israel", International Business Times, 9.august 2012; og "In Turnabout, Syria Rebels Cet Libyan Weapons", New York Times, 21.juni 2013.

60 Jeg står i gjeld til Thomas Pierret for denne observasjonen. Thomas Pierret, "Salafis at War in Syria: Logics of Fragmentation and Realignment», Forelesning, Senter for islam og midtøstenstudier (SIMS), Universitetet i Oslo, 25. august 2014.

61 For en diskusjon om teorier rundt politisk vold og smitteeffekt, se Brigitte L Nacos, "Revisiting the Contagion Hypothesis: Terrorism, News Coverage, and Copycat Attacks", Perspectives on Terrorism, 3 (3) (2009).

62 David Rapoport, "The Four Waves of Modern Terrorism”, A. K. Cronin \& J. M. Ludes (red.), Attacking terrorism: Elements of a grand strategy. Washington, DC: Georgetown University Press, s.43-76.

63 For jihadistbevegelsen blir militære nederlag i et land kun et taktisk tilbakeslag på ett frontavsnitt, ikke et ødeleggende strategisk nederlag. Ved å samle geografisk spredte jihadistgrupper i én ideologisk bevegelse kan man hele tiden feire militære seirer så lenge minst ett av de mange frontavsnittene har suksess. 